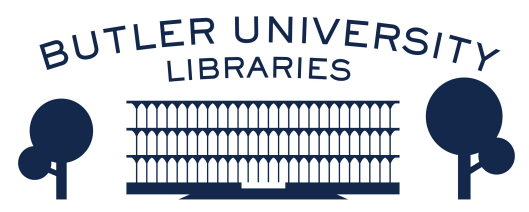

Journal of Hindu-Christian Studies

\title{
Agency in the Subaltern Encounter of Evil: Subverting the Dominant and Appropriating the Indigenous
}

James Ponniah

University of Madras

Follow this and additional works at: https://digitalcommons.butler.edu/jhcs

Part of the Christianity Commons, Comparative Methodologies and Theories Commons, Hindu Studies Commons, and the Religious Thought, Theology and Philosophy of Religion Commons

\section{Recommended Citation}

Ponniah, James (2016) "Agency in the Subaltern Encounter of Evil: Subverting the Dominant and Appropriating the Indigenous," Journal of Hindu-Christian Studies: Vol. 29, Article 7.

Available at: https://doi.org/10.7825/2164-6279.1630

The Journal of Hindu-Christian Studies is a publication of the Society for Hindu-Christian Studies. The digital version is made available by Digital Commons @ Butler University. For questions about the Journal or the Society, please contact cbauman@butler.edu. For more information about Digital Commons @ Butler University, please contact digitalscholarship@butler.edu. 


\title{
Agency in the Subaltern Encounter of Evil: Subverting the Dominant and Appropriating the Indigenous
}

\author{
James Ponniah \\ University of Madras
}

THIS essay focuses on subaltern encounter of evil that occurred in two different religious orbits, namely, Hinduism and Christianity in India. The Hindu phenomenon to be studied is Ayya Vali ${ }^{1}$ (henceforth, AV) founded by Ayya Vaikundar (1809-1851) and the Christian phenomenon, Bible Mission (henceforth, BM) established by Devadas Ayyagaru (1840-1960). While attempts have been made earlier in the writings of Chad Bauman, Zoe Sherinian, Eleanor Zeliott, Sathianathan Clarke and G.Patick ${ }^{2}$ to study the relation between religion and subaltern agency in India, this work has a different focus in that it employs the idea of subaltern agency to discuss the parallel ways through which two nominally Hindu and Christian movements, originating from two different backgrounds and time periods, have developed a subaltern theodicy, borrowing from classical and local traditions, to offer a means for critiquing domination and overcoming marginalization.

While there is ample literature both on Christian and Hindu theodicy more broadly, this article's contribution is to look at the respective theodicy through subaltern lens. While most of the existing works of theodicy in both the traditions revolve around philosophical debates that try to reconcile one's belief in the existence of God with the fact of evil, my endeavour here is to delineate how both Vaikundar and Devadas addressed theodicy with a subaltern programme of action. Because Vaikundar chose to situate theodicy within the context of social discrimination and religious exploitation of his time, he proposed various measures to conquer evil, evil which manifested itself in inequality, caste-oppression etc., Similarly, through various ways to be discussed below, Devadas too designed a new programme of theodicy by incorporating practices from the domain of folk culture, thereby empowering the religiously marginalised lay people. They both exercised subaltern agency in evolving concrete strategies to empower the subalterns to encounter evil. Before focusing on their strategies, let me first furnish an overview of these two movements.

\section{Introducing the Phenomena under Study}

Ayya Vali is one of the contemporary 'Hindu' religious movements spread primarily among the Cānāars (also known as Nātārs now) in the southern districts of Tamilnadu (especially in Kanyakumari District). This religious movement was founded in the latter part of $19^{\text {th }}$ century by Muthukuttisamy, popularly known as Ayya Vaikundar (b. 1809) and grew so rapidly in the $19^{\text {th }}$ and $20^{\text {th }}$ centuries among the low caste people (especially among the Cānārs) that the movement is estimated to have seven hundred thousand adherents all over the world today. Ayya Vaikundar was born as a Cānār (whose 
occupation then was toddy-tapping) in the princely state of Travancore-ruled according to the Brahminic varnashrama dharma ideology and, as a result, the low caste Cānārs suffered multiple forms of discrimination. ${ }^{3}$ Vaikundar identified himself totally with the oppressed masses, especially with the cānārs and interpreted their experiences of caste discrimination, injustice and exploitation as prevalence of kali, i.e., evil power. ${ }^{4}$ AV understands kali as an all-pervasive evil power that is both cosmic and personal, invisible and visible. While describing in various idioms kali's pernicious presence throughout all aeons, AV frames Kali Yuga as the full maturation of kali whose embodied form is none other than the king of Travancore himself. Though his official name was Swathithirunal, Vaikundar named him Kalineecan ('personification of evil'). Even as he held Kalineecan responsible for the miseries of the downtrodden, Vaikundar claimed himself to be an avatar of Vishnu whose mission was to launch a decisive battle against various forms of evil (kali) and to inaugurate Dharma Yuga. Both his views on Kali Yuga and his vision of Dharma Yuga, as described below, were framed as an emancipatory project for the subaltern masses.

The contemporary Christian phenomenon to be explored in this paper is Bible Mission, founded in 1938 by a Dalit Lutheran layman, Mungamuri Devadas, popularly known as Ayyagaru (Father) Devadas in Andhra Pradesh, India. ${ }^{5}$ Devadas served in the Lutheran Mission both as a teacher in the seminary and a warden of the boarding house for the boys at St. Paul's Church, Rajamundry. Devadas was a powerful preacher held in high esteem by all. But trouble started when he openly talked about visions and dreams through which one can communicate with God, something about which the Lutheran Church did not approve. After several warnings and arguments, his services of forty-six years as a touring evangelist in the American Evangelical Lutheran Mission were officially terminated as of March 1, 1938. In the same year, he found an independent Pentecostal movement called Bible Mission. Of late, the Bible Mission has become a force to be reckoned with in Andhra Pradesh, one of the southern states of India. The state witnesses a mammoth gathering of nearly three to four hundred thousand people for its annual meeting at Pedakakani in Gunter district normally held in the last week of January. BM is a unique phenomenon not only because of its popularity but also for its distinctive practices as discussed below. Though Devadas' view of evil was a traditional Christian idea, namely, evil as the work of the devil, his battle against evil was a digression from his former Lutheran Church to include local beliefs and practices.

\section{Exploring Common Grounds and Strategies in Subaltern Encounter of Evil}

When we analyse the origin, the vision and the contributions of these two religious leaders, subalternity and peripherality seem to undergird both these phenomena. Both hailed from a low caste subaltern background. One (Devadas) was a Dalit and the other (Vaikundar) was a Cānār, one of the most oppressed groups in Southern Travancore. Both found their religious leadership outside mainline religious traditions. Having defected from the Lutheran Church, Devadas started his own indigenous Pentecostal Church, BM. Vaikundar, being a low caste Cānār, was never part of mainline Hindu religion and founded his own brand of religion called AV. Both lived on the margins of society, leading a very simple ordinary ascetic life, 
befitting a sadhu in the Indian tradition. Both worked for the marginal groups. Devadas worked for the religiously marginalised, the ordinary lay people whose needs were largely ignored in the clergy-centred mainline Churches. ${ }^{6}$ Unlike the Lutheran Church characterised by top-heavy administrative structures, Devadas made BM a self-governed church in which ordinary local people enjoyed autonomy by actively participating in and managing the day-to-day affairs of the Church. ${ }^{7}$ Vaikundar worked primarily for the socially marginalised, the Cānārs who were placed on the periphery of the fourfold caste system. Considered a little above Pallars and Parayars, Cānārs were still regarded as polluting and had to maintain a physical distance from the high castes. They had to keep thirty-six paces away from Brahmins and twelve from Nayars. Their women were allowed neither to cover their breasts, nor to wear shoes or golden ornaments. ${ }^{8}$ While their background of marginality did influence their views on evil as noted above, it also drove them to exercise subaltern agency to invent various strategies to carry out a programme of emancipation from various forms of evil. To begin with, both the leaders exercised subaltern agency to identify marginality itself as a form of evil to be addressed, confronted and overcome. It is to be noted that while the campaign against marginality was more pronounced and well articulated in Vaikundar, it was rather subtle and circumspect in the case of Devadas. Secondly, while identifying themselves with the marginal people, both the leaders exercised subaltern agency to make new claims, which were anti-establishment and subversive, to earn for themselves a special status that would legitimize their proposals of subaltern theodicy. For instance, Devadas claimed that, in bright daylight, God wrote two words-Bible Mission-in the air and told him "to come out as a prince of an army." Subsequently, this command resulted in the foundation of a Pentecostal church called BM. Further, by claiming that he had direct access to God and His plans through dreams and visions, Devadas constructed a new source of authorityextraneous to the Lutheran Church-to legitimize his teachings and practices. While he rejected the invitation to be ordained as a minister in the Lutheran Church, he-after his expulsion-not only claimed that he was directly ordained by God in a vision, but exercised self-assumed authority to ordain one of his followers as a minister. ${ }^{10}$ Similarly, though born in a low caste Cānār family, Vaikundar, as mentioned above, declared himself to be an avatar of Vishnu, a blasphemous claim in the eyes of Brahminic Hinduism.

Thirdly, they also exercised agency to build their campaign against evil upon indigenous categories, and in the process constructed their religious phenomena as eclectic. Even as he spoke extensively about the demons and evil spirits, Devadas integrated into his teachings the common Hindu folk's beliefs and practices related to devils. For instance, just as in a Hindu folk temple, he introduced for his people Christian mantras (prayers), which he himself formulated, to be used as exorcist spells to cast out demons. He also introduced the practice of writing divorce letters to the devil. Further, Devadas also incorporated the Hindu folk practice of speaking with the dead into the fellowship of the departed spirits. Thus, while innovating new strategies to take on evil in the world, Devadas responded to the common folk's sensibilities, evolved a 'people's weapon' to fight evil, and built his BM church on eclectic 
practices. Similarly, even as he claimed to be an avatar of the Sanskritic God Vishnu, Vaikundar adopted folk religious practices such as trance and kanakku (divination) to incinerate the evil spirits, ${ }^{11}$ thereby making AV a fusion of the classical and the folk traditions. Having emerged from the ocean of Tiruchendur, one of the six abodes of the Tamil Saivite deity Murugan, Vaikundar announced himself to be an avatar not of Siva but of Vishnu, Further, Vaikundar became eclectic when he claimed to have been married through ekanai kalyānam

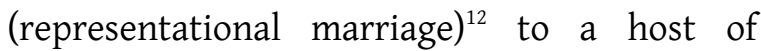
goddesses from different Hindu religious traditions such as Parvathi, Valli, Lakshmi and Theivanai to unite them all in him so that he could become super-powerful to launch a decisive battle against kali in this Yuga.

Fourthly, both the leaders, in the implementation of their emancipatory project, exercised subaltern agency to undermine beliefs and customs which they saw as practices of domination and forms of exploitation in their respective mainline religious traditions. Contrary to the then existing Lutheran practice, Devadas encouraged his followers to explore alternative ways of communicating with God, not only through visions and dreams but also through fellowship with the dead, as mentioned earlier, especially with the spirits of saintly people like Sadhu Sundar Singh. He argued that such practices were compatible with the Biblical world-view. In doing so, Devadas, as a Pentecostal religious leader, undermined the existing institutional practice of mediating the divine through the hierarchy of the mainline churches, and thus redefined the power relations between the laity and the clergy.

Similarly Vaikundar also overturned the long-held beliefs and practices of the dominant groups in mainline Hinduism. For instance, he rejected idol worship and ritual offerings as they both facilitated and legitimized the exploitation of the common people by the temple priests. Further, he also sought to dismiss the dominant Sanskrit discourses of that time which exalted Travancore king's reign as 'Hindu State par excellence', since it upheld varnashrama dharma ideology and its unjust hierarchical structure. According to Sanskritic Hinduism, doing charity to the Brahmin priests is a supreme dharma. The king of Travancore who implemented this dharma fastidiously at the time of Vaikundar was praised as a dharmakarta (exemplar of dharma), since he fed hundreds of Brahmins every day but at the expense of the poor who were heavily taxed to support this practice of dharma. He imposed on the Cānārs various types of taxesnearly three hundred of them-which included tax for the palm trees, right to grow hair and to wear gold ornaments, taxes for women's breasts, taxes not only for the living but also for the dead. ${ }^{13}$ The high castes made the low castes bonded labourers and extracted free labour from them, but called it ūliyam (service). Vaikundar questioned such exploitative customs, and took upon himself the challenge of correcting this unjust situation in many ways: He described the reign of Travancore State as the climax of the spread of kalimayai (illusionary power of evil) since it discriminated against the low caste people in every way; he claimed that the important mission of his avatar was to end kalimayai spread in the kingdom; he openly declared, as mentioned earlier, that the other purpose of his Vaikunda Avatar is to inaugurate an egalitarian Dharma Yuga.

Fifthly, while attempting to torpedo the then existing lopsided ideas and beliefs, both the leaders exercised subaltern agency to introduce 
new and nuanced meanings into these notions to render them more inclusive and liberative so as to fit them into their vision and agenda. For instance, in line with his declaration that he came to usher in Dharma Yuga, Vaikundar redefined the very notion of tarmam (Sanskrit dharma) with a new dictum "Tālakitapārai tarkapppatuve tarmam" i.e., to protect the lowly is tarmam. ${ }^{14}$ In doing so, he sought to universalise the notion of dharma itself. Thus he privileged the low castes over the high castes and made them special beneficiaries of his new dharma in sharp contrast to the varnashrama system which primarily contributed to the well-being of the high-castes but neglected that of the low castes and untouchables. To counter the king's practice of feeding the Brahmins, he introduced annnatānam (free meal) which was served in AV temples to all guests irrespective of caste, class, gender and age. Vaikundar's universal dharma covered not only the subalterns and other human beings but also the whole of cosmosanimals and plants, mountains and rivers. Akilattirațu, the scripture of AV, contains a number of passages in which Vaikundar imparts good dharma to the living and the non-living beings in the world and calls upon them to live in peace with one another, even as he exhorts them not to fight and discriminate on account of physical size/strength. Just as Vaikundar wanted to end the evil of violence among the non-humans and ensured the well-being of all beings in the universe, ${ }^{15}$ so also he redrew the power relations between the powerful and the powerless both in the human and the cosmic world.

Likewise, Devadas too exercised subaltern agency to reinterpret the idea of revelation. He argued that in order to bring people to Him, God continues to reveal his plans in visions and prayers. He held a popular Hindu view that great hermits like Sadhu Sundar Singh and other saints are wandering around the earth and can appear to people at their will to talk to them and bring them to God. Communicating with the departed souls and receiving a message from them have become a common practice in BM. It is a special practice at their meetings to place in the corner of the prayer hall an empty chair, carefully covered with white linen, so that the spirit of Devadas can come down to be with the followers of BM. Similarly, AV also has a practice of placing in their temples an empty chair which they call āsanam (seat) which they believe is occupied by Vaikundar himself.

Even while exercising subaltern agency and deploying multiple strategies to wage war against kali and Satan, both the leaders realised the almost insurmountable challenges of their task. They both held that evil power had a near inescapable sway over people and their behaviour. For Vaikundar, kali is ubiquitous and subtle in this Kali Yuga unlike the previous six ages. ${ }^{16}$ He drew his followers' attention to the nature of kali as an inner power of evil that reigns over the minds and hearts of people living in this age and makes everyone act against unmai (Truth). Hence, the battle against kali has to be waged primarily in the minds of human beings. That is why Vaikundar said 'kali eñrāl eli allavē, kanaiyā li vēnțāme ${ }^{17}$ meaning 'kali is not a mouse and you do not need any hammer to kill it'. Similarly, Devadas also held that Satan always seeks to occupy the minds of humans. His attractions, the worldly ways, are so powerful that humans can be trapped as his slaves forever. It is because of this that he introduced the practice of writing divorce letters to Satan to end this bondage. 
Further, both of them believed that keeping oneself clean inwardly and outwardly, spiritually and physically, is an important way of overcoming the invisible power of evil. Devadas espoused the idea of "personal and community holiness' which demanded from his followers a rigorous pursuit of values of cleanliness, self-control and abstinence. He taught that God's children should be holy and pure as God is. Just as he ensured that both inside and outside of the places of worship be kept clean, Devadas also insisted on practices of personal cleanliness and self-control such as wearing washed clothes for prayer, washing one's feet before worship, fasting and avoidance of liquor. In doing so, Devadas claimed to follow a Telugu folk proverb, 'A clean pot for cooking food, a clean body and a clean heart for worshipping God.' Likewise, Vaikundar too called upon his followers, the marginal people, to undertake tapas (practices of selfmortification and self-restraint-avoidance of meat and alcohol) not only to discipline oneself and to restore self-respect, but also to build up the inner capacity to counter the presence of kali in the outer world. Thus both men insisted on physical cleanliness and inner purity primarily for two reasons. Both saw purity as a necessary condition to tap the divine power to take on evil. Secondly, both realised that their followers, given their poor economic background did not care to keep themselves clean and neat. Hence, they could only hold low social status against Brahminical purity. Knowing well that the subordination of the low castes was caused by the stigma of impurity ascribed to them by the high castes, both decided to confront this social evil by imparting practices of cleanliness and abstinence to the marginal people. ${ }^{18}$ The practices of physical cleanliness did yield desirable results and earned respectability for the subalterns. For instance, the LMS (London Missionary Society) report of the year 1892 reads: "It is true that their (i.e. of the devotees of Vaikundaswamy) bodies and their houses are more cleanly [sic] than those of the rest." 19

In doing so, both leaders demonstrated their intuitive understanding of the relationship between power and values. The axis of purity/impurity operative overtly or covertly in multiple contexts and myriad situations in India $^{20}$ is built on a dichotomous value framework that associates the values of cleanliness, temperance and vegetarianism with Brahminical purity but assigns the lowest social status to the low castes and the untouchables who are structurally devoid of the possibility of practising such values. The monopoly of such values by dominant castes and their display of such values in the public domain as identity markers of certain castes earned for them high social status in the hierarchical Indian social order. As a result, certain values like purity and cleanliness came to "possess that element of power which permit dominant classes to subjugate subordinate classes (as impure) with a minimum use of physical force. ${ }^{21}$ By appropriating the values of cleanliness, selfrestraint and vegetarianism, these subaltern leaders have not only challenged and undermined the monopoly of the dominant groups over these values, they have also demonstrated their subaltern agency by making these values new symbolic capital to the subalterns, thereby democratizing such values. In doing so, they sought to deprive the dominant groups of their 'weapons of symbolic violence' that helped them subjugate the subordinate groups on account of impurity. In exhorting 
their followers to espouse the value of purity, these two subaltern leaders attempted to confront head-on the social evil of pollution and untouchablity.

While viewing evil as a powerful force to reckon with, both the leaders did not see the common people as passive victims and mute spectators. Their direct experience of $\operatorname{God}^{22}$ on the one hand and the encounter of evil on the other drove both the leaders to innovate for their subaltern people new ways of encountering evil powers wherein the agency was placed in the hands of the people and not in the intermediaries. For instance, by providing the common people with a set of prayers and exorcist spells to cast out demons, and by introducing the practice of writing divorce letters to the devil, Devadas empowered them to overcome evil on their own. Further, while developing the $\mathrm{BM}$ as a unique Pentecostal church by popularising the idea of communication with God through dreams and visions, Devadas also showed the common folk in India that each one of them can have one's own direct relationship with and non-mediated experience of God and can use these immediately available resources to conquer evil. Having conquered Satan and his evil powers, his followers would be elevated to the status of bridal church and privileged to be in the Kingdom of Heaven. Similarly, Vaikundar also declared that he came to inaugurate the Dharma Yuga which is to be carried forward by the followers of AV with the help of Cānrōors, the

\section{Notes}

${ }^{1}$ All Tamil words in this article, except the names of persons, gods and goddesses, are italicized and transliterated according to Tamil Lexicon, Madras: University of Madras, 1982. Common Sanskrit words noble ones. Cānnrōrs were a select group of Cāṇārs who were given divine parentage in AV's mythology. By making them transformative agents of Dharma Yuga, Vaikundar assigned an important role to the erstwhile subalterns who would serve as interface between the evil order of Kali Yuga and the just order of Dharma Yuga.

Thus, through the production of new narratives and the introduction of innovative practices in favour of the subaltern folk, both the leaders provided the common people with directly accessible alternative keys to divine energies. This shows that they both refused to place the marginal people at the receiving end. Rather both Vaikundar and Devadas made the subalterns active agents and citizens of Dharma Yuga and Kingdom of Heaven respectively.

\section{Conclusion}

This essay has explored how two different religious leaders belonging to different historical periods and cultural backgrounds had acted in a remarkably similar way to exercise subaltern agency and to deploy innovative strategies to encounter evil. Their strategies can be viewed as a programme of liberation for the subalterns in that they subverted the dominant discourses, broke the monopoly of certain powerful groups over cleanliness and divine mediation, made new claims in support of their liberative agenda, drew upon common people's cultural resources to introduce eclectic practices and empowered the subalterns to tackle evil in concrete terms.

(including other non-Tamil words) such as avatar, Sadhu, dharma, varnashrama dharma, mantras, Kali Yuga, Dharma Yuga etc., are not transliterated but italicized. 
${ }^{2}$ See Chad M. Bauman. Christian Identity and Dalit Religion in Hindu India, 1868-1947, Grand Rapids, Mich.: William B. Eerdmans. 2008; Zoe Sherinian, Folk Tamil Music as Dalit Liberation Theology, Bloomington, Indiana: Indiana University Press, 2014 ; Sathianathan Clarke, Dalits and Christianity: subaltern religion and liberation $t$ heology in India, Delhi ; New York : Oxford University Press, 1998 http://dx.doi.org/2027/mdp.39015043092652; G Patrick, Religion and Subaltern Agency, Chennai: University of Madras, 2003.

${ }^{3}$ See G Patrick, Religion. pp. 23-60.

${ }^{4}$ For AV's unique understanding of kali as evil power, see James Ponniah, “Alternative Discourses of Kali Yuga in Ayya Vali," Nidan: An International Journal for the Study of Hinduism. July 2014, pp. 65-85.

${ }^{5}$ See Solomon Raj, A Christian folk-religion in India: a study of the small church movement in Andhra Pradesh, with a special reference to the Bible Mission of Devadas, New York: P. Lang, 1986. http://dx.doi.org/2027/mdp.39015078372227

${ }^{6}$ Ibid., p. 10.

7 See James Ponniah, "The Eruption of the Autonomous and the Birth of 'Bible Mission': Exploring an Instance of Lay Leadership in India" in Thomas Cotti (Ed). Many Tongues, One Spirit: Local Ecclesiologies in Dialogue. Berkeley: Jesuit School of Theology in Berkeley, Santa Clara University, 2013, pp. 59-74.

${ }^{8}$ See Patrick, Religion, pp. 27-28.

${ }^{9}$ Solomon Raj, Christian folk-religion, p. 26

${ }^{10}$ Ibid., p. 32.

${ }^{11}$ Patrick, Religion, p. 80.

${ }^{12}$ Patrick, Religion, p. 94.

${ }^{13}$ Ibid., p. 45.
14 Muthukuttisamy, Akilattirațtu Ammānai, Susintharam: Star Press, 1185 (13 ${ }^{\text {th }}$ edition), p. 221.

${ }^{15}$ Mani Bharathi, Akilattirațtu Vilakkaurai. Vol.II, Chennai: Thirunamapuhazh Press, 2003, p. 81.

${ }^{16}$ AV's mythology of Yugas believes in a total of eight aeons or Yugas. They are Neetiya Yuga, Chatura Yuga, Nedu Yuga, Kretha Yuga, Treta Yuga, Dvapara Yuga, Kali Yuga and Dharma Yuga. The first three Yugas and the last Yuga would have no parallels in the mainstream Hindu mythology.

${ }^{17}$ Akilattiratțu, 224.

${ }^{18}$ It may be noted that Ghasidas (1756-1850) and Narayana Guru (1856-1928) prescribed similar codes of conduct for the low caste Chamars and Elavās respectively.

${ }^{19}$ As quoted in Patrick, Religion, p. 97.

${ }^{20}$ While a fuller consideration of the key Indian categories of purity/pollution (or auspiciousness/ inauspiciousness) lies beyond the scope of the present paper, important works on this idea include John B. Carman and Frederique A. Marglin (eds.,) Purity and Auspiciousness in Indian Society, Leiden: E. J. Brill. 1985; Louis Dumont and D.F. Pocock, 'Pure and impure', Contributions to Indian sociology, 3: 9-39, 1959 http://dx.doi.org/2027/mdp.39076000775515; M.N. Srinivas, Religion and society among the Coorgs of south India, Oxford: Clarendon Press, 1952. http://dx.doi.org/2027/umn.31951001521980t

${ }^{21}$ David Hardiman, The Coming of Devi: Adivasi Assertion in Western India, Delhi: Oxford University Press, 1987, p.163.

${ }^{22}$ The followers of AV believe that Muthukutti, before he claimed himself to be Vaikunda avatar, disappeared into the Tiruchendur ocean for three days during which time Vaikundar had a direct vision of and conversation with all Hindu gods and goddesses. 